УДК 340

\title{
ПЕРСПЕКТИВЫ РАЗВИТИЯ ПРОФЕССИОНАЛЬНОГО ПРЕДСТАВИТЕЛЬСТВА В АРБИТРАЖНОМ ПРОЦЕССЕ
}

\author{
Насыров Рамис Рамильевич \\ студент магистрант \\ Научный руководитель: Скачкова Ольга Сергеевна \\ к.ю.н., доцент
}

ФГАОУ ВО «Самарский государственный экономический университет»

Аннотация: Статья посвящена перспективам развития института профессионального представительства в арбитражном процессе. Рассмотрен вопрос введения адвокатской монополии на территории Российской Федерации в целях решения проблем института представительства. Приведены положительные и отрицательные моменты адвокатской монополии.

Ключевые слова: право на судебную защиту, представитель, представительство в арбитражном процессе, профессиональное представительство, перспективы развития профессионального представительства, адвокатская монополия.

\section{PROSPECTS FOR THE DEVELOPMENT OF PROFESSIONAL REPRESENTATION IN THE ARBITRATION PROCESS}

\author{
Nasyrov Ramis Ramilevich \\ Scientific adviser: Skachkova Olga Sergeevna
}

\begin{abstract}
The article is devoted to the prospects for the development of the institute of professional representation in the arbitration process. The article considers the issue of introducing a lawyer monopoly on the territory of the Russian Federation in order to solve the problems of the institution of representation. The positive and negative aspects of the lawyer monopoly are given.

Key words: right to judicial protection, representative, representation in arbitration proceedings, professional representation, prospects for the development of professional representation, lawyer monopoly.
\end{abstract}


Участие профессиональных представителей в арбитражном процессе оказывает положительное влияние на эффективность и качество судопроизводства, осуществляемого арбитражными судами. Потребность в профессиональных представителях обусловлена, прежде всего, особым (экономическим) характером рассматриваемых арбитражными судами споров, лиц, не обладающих соответствующим образованием и знаниями, с одной стороны, как правило, не способствует эффективной защите их прав, а с другой - объективно затягивает рассмотрение дел.

При этом представляется очевидным, что судебное дело, в котором принимает участие профессиональный представитель, как правило, будет рассмотрено значительно быстрее, нежели дело, в котором лица самостоятельно представляют свои интересы.

С 1 октября 2019 года был внесен ряд изменений в процессуальное законодательство Российской Федерации. В частности, был введён образовательный ценз для представителей в арбитражном судопроизводстве, то есть с 01.10.2019, чтобы быть представителем в арбитражном процессе, нужно иметь высшее профессиональное образование по специальности «Юриспруденция». Поэтому помимо доверенности в судебное заседание необходимо принести и документ подтверждающий наличие высшего юридического образования. Образовательный ценз не распространяется на патентных поверенных по спорам об охране интеллектуальной собственности, арбитражных управляющих в делах о банкротстве. Кроме того, правило не действует для законных представителей [1].

Таким образом, в соответствии с новыми правилами представитель может быть допущен к участию в судебном заседании при условии представления следующих документов:

- документ, удостоверяющий личность;

- доверенность;

- диплом о высшем юридическом образовании либо документ, подтверждающий ученую степень по юридической специальности.

Данное правило не касается адвокатов, которые вправе использовать адвокатское удостоверение вместо документа, удостоверяющего личность, и диплома о высшем юридическом образовании.

Новые требования к представителям в арбитражном процессе повысили статус юристов. До этого нововведения в суде могли исполнять роль 


\section{ИННОВАЦИОННАЯ ТРАЕКТОРИЯ РАЗВИТИЯ СОВРЕМЕННОЙ НАУКИ:

представителей, лица без надлежащего образования, не обладающие должной квалификацией.

Однако, в настоящее время существует проблема отсутствия порядка проверки достоверности диплома представителя, и такой обязанности на суд закон не возлагает. В связи с этим возникает вопрос о правовых последствиях установления факта отсутствия у представителя лица, участвующего в деле, необходимого образования. Определенно, данное обстоятельство будет признаваться допущенной процессуальной ошибкой. Но возможно ли считать настолько существенной, что сам факт допуска представителя доверителем привёл к принятию неправильного решения [2, с. 19-21].

К сожалению, диплом о высшем юридическом образовании далеко не всегда говорит о компетентности представителя.

Таким образом, на данный момент есть определённая недоработка введенного требования о наличии высшего образования с точки зрения практики. Решением данной проблемы, на мой взгляд, является введение адвокатской монополии на территории Российской Федерации. Перспектива введения адвокатской монополии позволила бы увеличить уровень правовой защиты получателей юридических услуг.

Под адвокатской монополией понимается объединение профессионалов для оказания квалифицированной юридической помощи по единому стандарту [3, с. 256-260]. Её введение совсем не преследует цели ограничение круга лиц, которые имеют право оказывать юридическую помощь. Наиболее значимыми задачами данного института является обеспечение равного доступа к юридическим услугам высокого качества, повышение уровня правовой культуры граждан, а также повышение эффективности деятельности судов и правоохранительных органов.

Доктор права Эссекского университета А. Н. Верещагинотметил, что «монополия требует очень развитой, масштабной системы бесплатной юридической помощи. Причем создание такой системы должно предшествовать монополии - последняя не может вводиться при смутных обещаниях того, что со временем широкая система бесплатной помощи будет введена». [4, с. 152-179].

На сегодняшний день в России адвокатская монополия предусмотрена в пределах уголовного процесса. Так, ч.2 ст. 49 УПК РФ указывает, что «в качестве защитников допускаются адвокаты. По определению или постановлению суда в качестве защитника могут быть допущены наряду с 
адвокатом один из близких родственников обвиняемого или иное лицо, о допуске которого ходатайствует обвиняемый. При производстве у мирового судьи указанное лицо допускается и вместо адвоката» [5]. Следовательно, близкие родственники обвиняемого и иные лица являются дополнительными защитниками наряду с профессиональным адвокатом.

Во всех остальных видах судопроизводства Российской Федерации пока ещё действует свобода судебного представительства.

Как полагает Министерство юстиции, только члены профессиональных юридических ассоциаций адвокатуры имеют достаточные знания для реализации указанного закона на территории Российской Федерации. Реформирование сферы юридических услуг с точки зрения публичных интересов направлено на решение проблемы, связанной с обеспечением юридических лиц, а также граждан профессиональной юридической помощью, гарантированной ст. 48 Конституции РФ [6].

Положительными аспектами данной реформы являются:

- профессионализм представителя, который подтвержден адвокатским статусом, и как следствие

- высокое качество защиты прав граждан;

- ответственность адвоката за качество работы, подкреплённая кодексом адвокатской этики и контролем со стороны адвокатской палаты.

Рассматривая вопрос о перспективах введения адвокатской монополии, следует также отметить и очевидные недостатки данной реформы. Любая монополия способствует снижению конкуренции на рынке, что также применимо и к рынку доставления и оказания юридических услуг. В связи с этим введение адвокатской монополии может привести к повышению цен на представительство в суде. [7, с. 284-287].

Таким образом, необходимо отметить, что введение адвокатской монополии является неоднозначным по своей природе способом улучшения качества юридической помощи. Введение адвокатской монополии может выявить как негативные стороны данной реформы, так и позитивные.

Предполагается, что введение монополии на представительство в арбитражном процессе, должно осуществляться постепенно.

\section{Список литературы}

1. Арбитражный процессуальный кодекс Российской Федерации от 24 июля 2002 г. № 95-ФЗ (ред. от 26 июля 2019 г.) (с изм. и доп., вступ. в силу с 1 октября 2019 г.) // СПС «КонсультантПлюс». 
2. Малов А. А. Требования к высшему юридическому образованию представителей в арбитражном процессе. Необходимость или соответствие тенденции современного судопроизводства // Арбитражный и гражданский процесс. - 2017. - № 12. - С. 19-21.

3. Берсенева Т. Вместо адвокатской монополии - адвокатская справедливость // Вестник Федеральной палаты адвокатов РФ. 2015. № 2. C. 256-260.

4. Верещагин. А. Н. К оценке обоснованности адвокатской монополии // Экономическая политика. 2017. № 2. С. 152-179.

5. Уголовно-процессуальный кодекс Российской Федерации от 18.12.2001 № 174-Ф3 (ред. от 11.10.2018) (с изм. и доп., вступ. в силу с 21.10.2018) // СПС «Консультант плюс».

6. Конституция Российской Федерации // СПС «Консультант плюс».

7. Горевая А. Г. К вопросу о монополизации адвокатской деятельности // Молодой ученый. - 2017. - №5. - С. 284-287.

(C) Р.Р. Насыров, 2021 